\title{
Spectrophotometric Determination of Penicillamine in Pharmaceutical Sample using Fe(III)-Tiron System
}

\author{
Xinrong WEN* \\ College of Chemistry and Environment \\ Jiaying University \\ Meizhou,Guangdong 514015,P.R.China \\ e-mail: wxrong5093@hotmail.com
}

\author{
Changqing TU \\ College of Chemistry and Environment \\ Jiaying University \\ Meizhou, Guangdong 514015,P.R.China \\ e-mail: tcq@jyu.edu.cn
}

\begin{abstract}
Hydrosulfuryl(-SH) in penicillamine molecule can reduce $\mathrm{Fe}(\mathrm{III})$ to $\mathrm{Fe}(\mathrm{II})$, then using tiron as chromogenic reagent of $\mathrm{Fe}(\mathrm{III})$, and the content of penicillamine is determinated indirectly through determinating the surplus content of $\mathrm{Fe}$ (III) in the system. An accurate fast spectrophotometric method for the determination of penicillamine by discoloration spectrophotometry using Fe(III)-tiron system has been established. The various effect factors on the determination of penicillamine using $\mathrm{Fe}$ (III)tiron system have been investigated in detail. The results show that when the reaction temperature was $85^{\circ} \mathrm{C}$, the reaction time was $20 \mathrm{~min}$, the dosage of pH3.0 buffer solution was $15.00 \mathrm{~mL}$, the dosage of $\mathrm{Fe}(\mathrm{III})$ was $2.30 \mathrm{~mL}$, the dosage of tiron was $1.00 \mathrm{~mL}$, the maximum absorption wavelength of the complex of $\mathrm{Fe}(\mathrm{III})$-tiron was $660 \mathrm{~nm}$, good linear relationship was obtained between $\triangle \mathrm{A}$ and the concentration of penicillamine in the range of $0.008000 \sim 0.04800 \mathrm{mg} \cdot \mathrm{mL}^{-1}$, the equation of the linear regression was $\triangle \mathrm{A}=0.0074+7.575 \mathrm{C}\left(\mathrm{mg} \cdot \mathrm{mL}^{-1}\right)$, with a linear correlation coefficient was 0.9993.This proposed method had been successfully applied to determinate of penicillamine in real pharmaceutical.
\end{abstract}

Keywords-penicillamine;Fe(III); tiron; discoloration spectrophotometry

\section{INTRODUCTION}

Penicillamine (PA, the molecular structure is shown in Fig. 1) is a sulfur-containing amino acid. Penicillamine is used in the treatment of rheumatoid arthritis, Wilson's disease, primary biliary cirrhosis, fibrotic lung disease, cystinuria and certain toxic metal poisoning. It is of great importance and significance for life science.

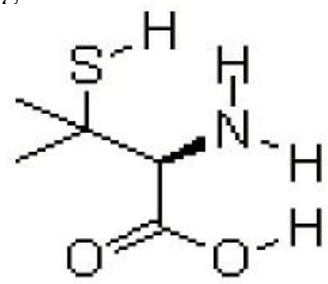

Figure 1. The molecular structure of penicillamine

Up till now, various different methods have already been applied for the determination of penicillamine, such as spectrophotometry [1, 2], fluorescence spectrophotometry $[3,4]$, flow injection analysis [5, 6], voltammetry [7, 8], capillary electrophoresis [9], HPLC method [10], HPLC-UV method [11], LC-UV method [12], chemiluminescence-LC method [13], electrochemical analysis [14], etc. However, most of the methods mentioned above need either complicated and expensive equipment or tedious procedures. These problems limit the practical application of these methods, and make them inapplicable in common laboratory. Therefore, it is essential and significant to develop a simple, accurate, rapid and sensitive method for the determination of penicillamine in clinical analysis and drug quality control.

In this paper, a novel method for the indirect determination of penicillamine by discoloration spectrophotometry using $\mathrm{Fe}(\amalg)$-tiron system has been established. The various effect factors on the determination of penicillamine were investigated in detail. The results showed that by controlling $\mathrm{pH}=3.0$, hydrosulfuryl $(-\mathrm{SH})$ in penicillamine molecule can reduce $\mathrm{Fe}(\amalg)$ to $\mathrm{Fe}$ (II), then using tiron as chromogenic reagent of $\mathrm{Fe}(\amalg)$, and the content of penicillamine was determinated indirectly through determinating the surplus content of $\mathrm{Fe}(\amalg)$ in the system.The maximum absorption wavelength of the complex of $\mathrm{Fe}(\amalg)$-tiron was $660 \mathrm{~nm}$, good linear relationship was obtained between $\Delta \mathrm{A}$ and the concentration of penicillamine in the range of $0.008000 \sim 0.04800 \mathrm{mg} \cdot \mathrm{mL}^{-1}$, the equation of the linear regression was $\triangle \mathrm{A}=0.0074+7.575 \mathrm{C}\left(\mathrm{mg} \cdot \mathrm{mL}^{-1}\right)$, with a linear correlation coefficient was 0.9993. This proposed method had been applied to determinate of penicillamine in real pharmaceutical, and the results agreed well with those obtained by pharmacopoeial method. This proposed method has the advantages of simply, rapidness, convenience, low analytical cost and so on.

\section{EXPERIMENT}

\section{A. Apparatus and Reagents}

A model 723S spectrophotometer (Shanghai Precision \& Scientific Instrument Co,. Ltd) was used for photometric measurements. A model UV-2401 UV-visible spectrophotometer (The Shimadzu Corporation, japan) was used for scanning the absorption spectrum.

A stock of standard solution of $1.000 \mathrm{~g} \cdot \mathrm{L}^{-1}$ penicillamine 
was prepared by dissolving $0.1000 \mathrm{~g}$ of penicillamine in $100 \mathrm{~mL}$ with bidistilled water and stored at $4^{\circ} \mathrm{C}$ in dark place, a working standard solution was prepared by appropriately diluting the stock standard solation. A stock of stand-ard solution of $0.2500 \mathrm{~g} \cdot \mathrm{L}^{-1} \mathrm{Fe}^{3+}$ was prepared by dissolving $1.0793 \mathrm{~g} \mathrm{NH} \mathrm{Ne}_{4}\left(\mathrm{SO}_{4}\right)_{2} \cdot 12 \mathrm{H}_{2} \mathrm{O}$ in $200 \mathrm{~mL}$ bidistilled water, $4.0 \mathrm{~mL} 3 \mathrm{~mol} \cdot \mathrm{L}^{-1} \mathrm{H}_{2} \mathrm{SO}_{4}$ was added, and then diluting it to $500 \mathrm{~mL}$ with bidistilled water. A stock of standard solution of $6.250 \mathrm{~g} \cdot \mathrm{L}^{-1}$ tiron was prepared by dissolving $0.6250 \mathrm{~g}$ tiron in $100 \mathrm{~mL}$ with distilled water. Buffer solutions of different $\mathrm{pH}$ were prepared as references [15].

All reagents were of analytical reagent grade. Bidistilled water was used throughout.

\section{B. Method}

Take two $25 \mathrm{~mL}$ volumetric flask, a suitable amount of $0.1000 \mathrm{~g} \cdot \mathrm{L}^{-1}$ penicillamine solution was transferred into one of the two $25 \mathrm{~mL}$ volumetric flask. Then $2.30 \mathrm{~mL}$ of 0.2500 $\mathrm{g} \cdot \mathrm{L}^{-1} \mathrm{Fe}^{3+}$ solution, $1.00 \mathrm{~mL}$ of $6.250 \mathrm{~g} \cdot \mathrm{L}^{-1}$ tiron solution and $15.00 \mathrm{~mL}$ of $\mathrm{pH}=3.0$ buffer solution were added into the two $25 \mathrm{~mL}$ volumetric flask, the solution was diluted to the mark with bidistilled water and mixed well. After these mixture reacted for $20 \mathrm{~min}$ at $85^{\circ} \mathrm{C}$ in water both and cooled back to room temperature, the absorbance $(\Delta \mathrm{A})$ of the blank solution $\left(\mathrm{Fe}^{3+}+\right.$ tiron $)$ was measured at $660 \mathrm{~nm}$ against the determination solution $\left(\mathrm{Fe}^{3+}+\right.$ penicillamine + tiron $)$.

\section{RESULTS AND DISCUSSIONS}

\section{A. Absorption Spectrum}

According to the experimental method, in the range of $500 \sim 750 \mathrm{~nm}$, the absorption spectrum of the blank solution $\left(\mathrm{Fe}^{3+}+\right.$ tiron $)$ and the determination solution $\left(\mathrm{Fe}^{3+}+\right.$ penicillamine+tiron) are shown in Fig. 2. It can be seen that the maximum absorption wavelength of the complex of Fe(III)-tiron is at $660 \mathrm{~nm}$. Therefore, measurement wavelength was chosen as $660 \mathrm{~nm}$.

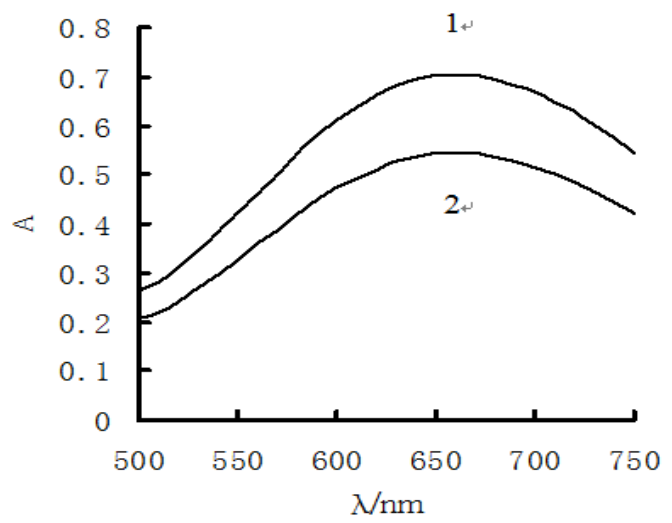

Figure 2. Absorption spectrum 1- $\mathrm{Fe}^{3+}+$ tiron, $2-\mathrm{Fe}^{3+}+$ penicillamine + tiron

\section{B. Effects of Reaction Temperature and Time}

The effect of temperature on absorbance $(\Delta \mathrm{A})$ was studied. The results showed that the absorbance $(\Delta \mathrm{A})$ reached its maximum and remained constant when the temperature was $85 \sim 90^{\circ} \mathrm{C}$. Hence, $85^{\circ} \mathrm{C}$ was selected for all further studies.

The absorbance $(\triangle \mathrm{A})$ of different reaction time $(5,10$, $15,20,25,30,35,40,45,50 \mathrm{~min}$ ) was measured at $85^{\circ} \mathrm{C}$. The results showed that the absorbance $(\triangle \mathrm{A})$ gets to its maximum and does not change when the time was 15 35min.Therefore, $20 \mathrm{~min}$ of reaction time was chosen for further experiments.

\section{Effects of Ph and The Dosage of Buffer Solution}

The effects of $\mathrm{pH}$ on absorbance $(\Delta \mathrm{A})$ were investigated. The results showed that the absorbance $(\triangle \mathrm{A})$ are maximal and remain constant when the $\mathrm{pH}$ was 2.8 3.0. Hence, pH3.0 buffer solutions was chosen and used for further studies.

The experimental results of the influence of the dosage of pH3.0 buffer solution showed that the absorbance $(\Delta \mathrm{A})$ reached maximal and does not change when the dosage of $\mathrm{pH} 3.0$ buffer solution is $12.50 \mathrm{~mL} \sim 15.00 \mathrm{~mL}$. Therefore, $15.00 \mathrm{~mL}$ of $\mathrm{pH} 3.0$ buffer solution was chosen.

\section{Effects of The Dosage of $\mathrm{Fe}(U)$}

The dosage of $\mathrm{Fe}(\mathrm{III})$ is regarded as an important factor. The effect of the dosage of Fe(III) on absorbance $(\Delta \mathrm{A})$ was studied(Fig. 3). As shown in Fig. 3, absorbance ( $\Delta \mathrm{A})$ reached maximal and kept constant when the dosage of $\mathrm{Fe}(\mathrm{III})$ was $2.30 \sim 2.50 \mathrm{~mL}$. Hence, $2.30 \mathrm{~mL}$ of the dosage of $\mathrm{Fe}(\mathrm{III})$ was chosen.

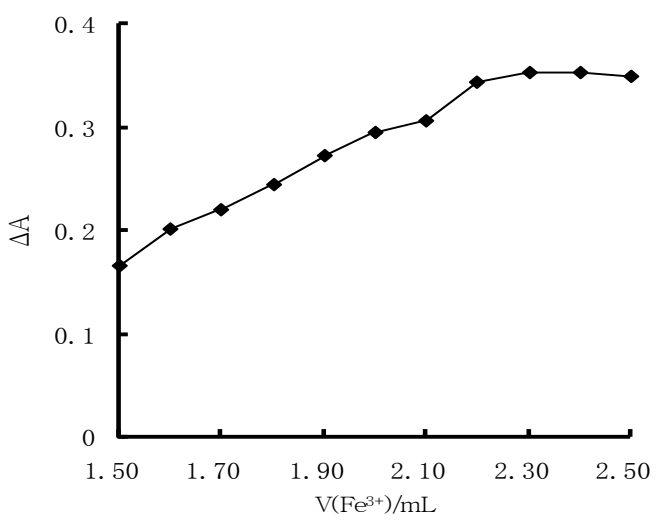

Figure 3. Effect of the dosage of $\mathrm{Fe}(\amalg)$

\section{E. Effects of The Dosage of Tiron}

The effect of the dosage of tiron on absorbance $(\Delta \mathrm{A})$ can be seen in Fig. 4. It is found from Fig. 4 that the absorbance $(\triangle \mathrm{A})$ reaches its maximum and keeps constant when the dosage of tiron was $0.80 \mathrm{~mL} \sim 1.60 \mathrm{~mL}$. Therefore, $1.00 \mathrm{~mL}$ of the dosage of tiron was chosen in the subsequent studies. 


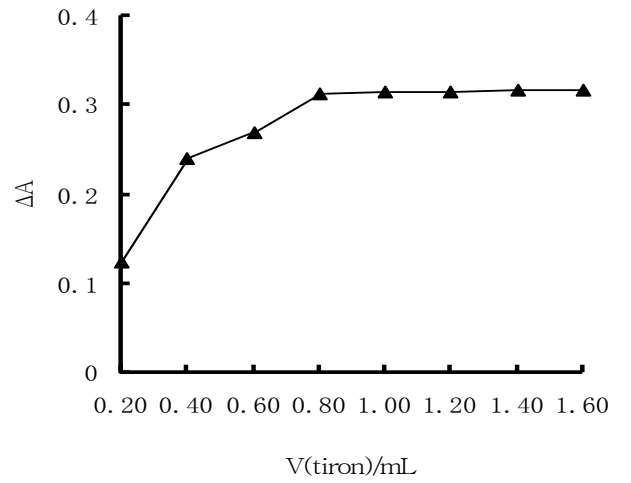

Figure 4. Effect of the dosage of tiron

\section{F. Interference of Coexisting Components}

A systematic study of the influence of excipients, carbohydrate and minerals on the determination of penicillamine was carried out. The tolerance levels were defined as standard deviation less than $\pm 5 \%$ within analytical determination. The conclusion is drawn from the following: $12 \mathrm{mg} \cdot \mathrm{mL}^{-1}$ glucose, sucrose, lactin, starch; $20 \mathrm{mg} \cdot \mathrm{mL}^{-1} \mathrm{~K}^{+}, \mathrm{Na}^{+}, \mathrm{Ca}^{2+}, \mathrm{Mg}^{2+}, \mathrm{Zn}^{2+}, \mathrm{SO}_{4}{ }^{2-}, \mathrm{CO}_{3}{ }^{2-}, \mathrm{NO}_{3}$ and $\mathrm{Cl}^{-}$do not affect the determination.

\section{G. Calibration Curve}

Under the selected conditions, a linear relationship between absorbance $(\triangle \mathrm{A})$ and the concentration (C) of penicillamine was obtained in the range of $0.008000 \sim 0.04800 \mathrm{mg} \cdot \mathrm{mL}^{-1}$ (Fig. 5). The linear regression equation is $\triangle \mathrm{A}=0.0074+7.575 \mathrm{C}\left(\mathrm{mg} \cdot \mathrm{mL}^{-1}\right)$, with a correlation coefficient of 0.9993 .

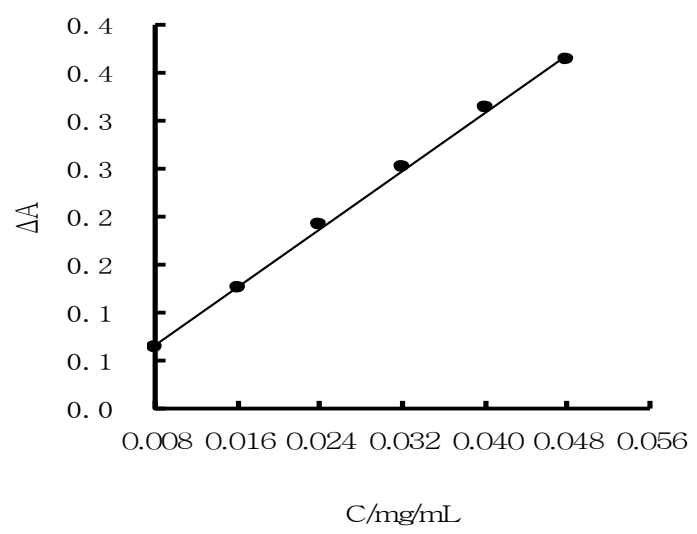

Figure 5. Calibration curve

\section{H. Determination of Penicillamine in Pharmaceutical Sample}

The proposed method was applied to the determination of penicillamine in penicillamine tablet. Meanwhile, the recovery tests of standard addition were performed. The result obtained was compared with those obtained by pharmacopoeia method, as show in Table I.

TABLE I. The DETERMinAtion Result OF PENICILlamine IN Penicillamine TABlet $\mathrm{N}=5$

\begin{tabular}{lc}
\hline Sample & Penicillamine tablet \\
\hline Proposed method $\left(\mathrm{m} \cdot\right.$ gtablet $\left.^{-1}\right)$ & 119.8 \\
RSD $(\%)$ & 0.3 \\
$\begin{array}{l}\text { Pharmacopoeia method[16] } \\
\left(\mathrm{mg} \cdot \text { tablet }^{-1}\right)\end{array}$ & 121.3 \\
Added $\left(\mu \mathrm{g} \cdot \mathrm{mL}^{-1}\right)$ & 12.00 \\
& 20.00 \\
Recovered $\left(\mu \mathrm{g} \cdot \mathrm{mL}^{-1}\right)$ & 11.96 \\
& 19.51 \\
Recovery $(\%)$ & 99.7 \\
\end{tabular}

Table I shows that the content of penicillamine in penicillamine tablet is $119.8 \mathrm{mg} \cdot$ tablet $^{-1}$ by this proposed method, and the content of penicillamine in penicillamine tablet is $121.3 \mathrm{mg} \cdot$ tablet $^{-1}$ by pharmacopoeial method. Obviously, the result of this proposed method agreed well with those obtained by pharmacopoeial method. It is indicated that the content of penicillamine in pharmaceutical sample can be accurately determined by discoloration spectrophotometry using Fe(Ш)-tiron system.

\section{CONCLUSION}

In this paper, a novel method for the indirect determination of penicillamine by discoloration spectrophotometry using $\mathrm{Fe}(\amalg)$-tiron system was reported. The proposed method has been successfully used for the determination of penicillamine in penicillamine tablet, and the results agreed well with pharmacopoeia method, the recoveries of standard addition were $97.6 \%$ 99.7\%. It is obvious that the determination of penicillamine by discoloration spectrophotometry using $\mathrm{Fe}(\amalg)$-tiron system has certain practical significance and foreground of application.

\section{REFERENCES}

[1] M. Reza Hormozi-Nezhad, M. Azargun, N. Fahimi-Kashani, "A colorimetric assay for d-Penicillamine in urine and plasma samples based on the aggregation of gold nanoparticles," J.Iran.Chem.Soc, 2014,11(5): 1249-1255.

[2] Corominas, B. Gómez-Taylor; Pferzschner, Julia; Icardo, M. Catalá; Zamora, L Lahuerta;Martínez Calatayud, J. "In situ generation of $\mathrm{Co}$ (II) by use of a solid-phase reactor in an FIA assembly for the spectrophotometric determination of penicillamine," 
J.Pharm.Biomed.Anal, 2005, 39(1/2): 281-284.

[3] Wang, Peng; Li, Bang Lin; Li, Nian Bing; Luo, Hong Qun. "A fluorescence detection of d-penicillamine based on $\mathrm{Cu}^{2+}$-induced fluorescence quenching system of protein-stabilized gold nanoclusters," Spectrochim.Acta.Part A, 2015, 135:198-202.

[4] Rasha Abdel-Aziz Shaalan. "Improved spectrofluori-metric methods for determination of penicillamine in capsules," Cent.Eur.J.Chem, 2010, 8(4): 892-898.

[5] Martinović, Anita;Cerjan-Stefenović, Štefica;Radić, Njegomir. "Flow Injection Analysis with Two Parallel Detectors: Potentiometric and Spectrophotometric Determination of Thiols and Ascorbic Acid in Mixture," J .Chem. Metrol, 2008, 2(1):1-12.

[6] P. Viñas, J.A. Sanchez-Prieto, M.Hernandez Cordoba. "Flow injection analysis and batch procedures for the routine determination of N-penicillamine," Microchem.J, 1990, 41(1): 2-9.

[7] J. B. Raoof, R. Ojani, M. Majidian, F. Chekin. "Homogeneous electrocatalytic oxidation of d-penicillamine with ferrocyanide at a carbon paste electrode: application to voltammetric determination," J.Appl.Electrochem, 2009, 39(6): 799-805.

[8] Shahrokhian, Saeed; Bozorgzadeh, Somayeh. "Electrochemical oxidation of dopamine in the presence of sulfhydryl compounds: Application to the square-wave voltammetric detection of penicillamine and cysteine," Electrochim.Acta, 2006, 51(20), 42714276.

[9] Yang, Xiupei; Yuan, Hongyan; Wang, Chunling; Su, Xiaodong; Hu, $\mathrm{Li}$; Xiao, Dan."Determination of penicillamine in pharmaceuticals and human plasma by capillary electrophoresis with in-column fiber optics light-emitting diode induced fluorescence detection," J.Pharm.Biomed.Anal, 2007, 45(2):362-366.
[10] Shu-Cai Liang;Hong Wang; Zhi-Min Zhang;Hua-Shan Zhang. "Determination of thiol by high-performance liquid chromatography and fluorescence detection with 5-methyl- $(2-(\mathrm{m}-$ iodoacetylaminophenyl) benzoxazole," Anal.Bioanal.Chem, 2005, 381(5):1095-1100.

[11] Kuśmierek, Krzysztof;Chwatko, Grażyna;Głowacki, Rafał;Bald, Edward. "Determination of endogenous thiols and thiol drugs in urine by HPLC with ultraviolet detection," J.Chromatogra.B:Anal.Technol.Biomed. Life.Sci, 2009, 877(28): 3300-3308

[12] Kuśmierek, Krzysztof;Bald, Edward. "Simultaneous determination of tiopronin and d-penicillamine in human urine by liquid chromatography with ultraviolet detection," Anal.Chim.Acta, 2007, 590(1):132-137.

[13] Z. Zhang, W.R.G. Baeyens, X. Zhang, Y. Zhao, G. Van Der Weken. "Chemiluminescence detection coupled to liquid chromatography for the determination of penicillamine in human urine," Anal.Chim.Acta, 1997, 347(3), 325-332.

[14] Fereshteh Chekin, Jahan-Bakhsh Raoof, Samira Bagheri, Sharifah Bee Abd Hamid. "Fabrication of Chitosan-Multiwall Carbon Nanotube Nanocomposite Containing Ferri/Ferrocyanide: Application for Simultaneous Detection of D-Penicillamine and Tryptophan," J.Chin.Chem.Soc, 2012, 59(11): 1461-1467.

[15] Chang, W.-B.; Li, K.-A. Brief Handbook of Analytical Chemistry; Beijing University Press: Beijing, 1981; p262. (In Chinese)

[16] The Pharmacopeial Committee of China. The Pharmacopoeia of the People's Republic of China (second-part); China Medical Science Press; Beijing, 2010, p428. (In Chinese) 